\title{
Micro-economic drivers of profitability in an ITQ-managed fishery: An analysis of the Queensland Coral Reef Fin-Fish Fishery
}

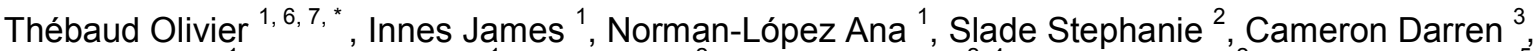
Cannard Toni ${ }^{1}$, Tickell Sharon ${ }^{1}$, Kung John ${ }^{2}$, Kerrigan Brigid ${ }^{2,4}$, Williams Lew ${ }^{2}$, Little L. Richard ${ }^{5}$

${ }^{1}$ CSIRO Marine \& Atmospher Res, Brisbane, Qld, Australia.

${ }^{2}$ QLD Dept Agr Fisheries \& Forestry, Brisbane, QId, Australia.

${ }^{3}$ Great Barrier Reef Marine Pk Author, Townsville, Qld, Australia.

${ }^{4}$ Conservat \& Fisheries Consulting, Marine Ecol, Brisbane, Qld, Australia.

${ }^{5}$ CSIRO Marine \& Atmospher Res, Hobart, Tas, Australia.

${ }^{6}$ UMR AMURE, Brest, France.

${ }^{7}$ Ifremer, France

* Corresponding author : Olivier Thébaud, Tel.: +61 738335971 ;

email address : Olivier.Thebaud@csiro.au

\begin{abstract}
:
An economic survey of the commercial operators currently active in the Queensland Coral Reef Fin-Fish Fishery has been carried out, as part of a research project aimed at evaluating alternative management options for this fishery. This paper presents the background analysis used as a basis to develop the sampling design for this survey. The background analysis focuses on activity patterns of the fleet based on effort and catch information, as well as patterns of quota ownership. Based on this information, a fishing business profile describing the micro-economic structure of fishing operations is developed. This profile, in conjunction with the qualitative information gained in undertaking the economic surveys, allows preliminary understanding of the key drivers of profitability in the CRFFF, and possible impacts of external factors on fishing operations.
\end{abstract}

\section{Highlights}

- The fisheries research and policy literature often refers to commercial operators as "Fishers". However, commercial fishing operations may present diversified business structures. We explore this diversity in the Coral Reef Fin-Fish Fishery on the Great Barrier Reef. Key dimensions include asset ownership, diversification of target fisheries and operation set-up. These may determine operation viability in the face of economic or environmental changes. 
Keywords : Commercial fishing, Queensland Coral Reef Fin-Fish Fishery, Great Barrier Reef, Business structures, ITQs, Diversification

\section{Introduction}

Decision-support tools used to assist in the evaluation of alternative fisheries management strategies increasingly seek to include the dynamic response of fishing operators to changes in their economic, ecological and/or regulatory circumstances [1] and [2]. This is because consideration of such responses may be critical in assessing the likely ecological, economic and social consequences of alternative management options [3], [4], [5] and [6], as well as of externally driven shocks such as climatic events [7]. In the fisheries modeling literature, as in the broader domain of fisheries research and policy analysis, the operators involved in commercial fishing are often referred to as "Fishermen" or "Fishers", with limited to no further specification. This is particularly true in the fisheries economics literature, as illustrated by Gordon's seminal work on developing a bio-economic theory of fisheries production dynamics [8], and the large body of research that developed on this basis. Since this research is concerned with the description of economic decisions made by commercial enterprises harvesting marine living resources, there has been a tendency to identify these enterprises with individual people involved in the business of fishing. To some extent, this may be justified by the fact that a large proportion of the world's commercial fishing activities are carried out by businesses that are held and operated by a single person, who owns and operates a single fishing vessel-the classic "owneroperator" fisher. However, there are also many cases in which the structure of commercial fishing businesses may be more complex, with multiple and varied individuals involved in the ownership and operation of fishing assets. When this is the case, commercial entities cannot be identified with particular individuals. In addition, such identification may be misleading as to the nature of the incentives and economic risks which businesses face, as these will depend on their business structure. This is particularly an issue if the aim of the research or policy analysis is to understand, and possibly influence, the incentives to which commercial fishing operations respond.

This paper presents an analysis of this issue using the Coral Reef Fin-Fish Fishery (CRFFF) on the Great Barrier Reef as a case study. The Effects of Line Fishing Simulator (ELFSim) was developed to examine 
potential management strategies for the CRFFF [9, 10]. ELFSim simulates the populations of coral trout (CT) and red-throat emperor (RTE) on almost 4,000 individual reefs. The model captures the spatial complexity of fish larval movement on the ocean currents, and the size, age and sex structure of the species across the region. In addition, ELFSim also simulates the fishing activity of commercial fishing operations across the region, as well as the charter and recreational components of the fishery. The platform contains an explicit representation of the behavior of commercial fishing operators, represented as individual, profit-maximizing agents. This includes fishing effort, its spatial and temporal distribution, as well as catch quota trading. This component of the model was developed and calibrated using economic data from the 1990s. At the time, the fishery was experiencing a transition from the landing of mostly dead fish, to the landing of both live and dead fish, the former attracting much higher prices. In mid 2004 the fishery also transitioned from a regulatory system based on input controls, to a mixed system that includes total allowable commercial catch limits and individual transferable quotas (ITQs), input restrictions, and increased marine reserves [11].

These changes led to the need for and fishing industry request to update the economic description of the fishery to be included in the simulation platform. This paper presents the approach taken to collect this information and the background analysis of the industry that was developed in the process. This involved identifying types of fishing businesses with similar characteristics actively involved in the fishery in the 2010-11 financial year, as well as a preliminary analysis of the structure of quota ownership in the CRFFF. This background analysis, as well as a preliminary understanding of the economics of the fishery derived from discussions with stakeholders in the process of defining the survey approach, allowed an economic profile of the businesses involved in the fishery to be determined. This profile, along with qualitative information obtained in the course of developing it, provides preliminary insights into the diversity of businesses that currently operate in the fishery, and how this may affect key drivers of profitability in the fishery at the micro-economic level.

\section{The commercial fishery}

The Queensland Coral Reef Fin-Fish Fishery consists of a commercial component, a recreational component and a charter component, with a small amount of take by Indigenous fishers [12]. The commercial fleet, which is the focus of the analysis presented in this paper, targets a diversity of coralreef associated fish using hand-held lines with baited hooks ( $>155$ species). The main species by order of decreasing value include several species of coral trout (Plectropomus and Variola spp., CT), landed predominantly as live fish and exported to Asia, as well as red-throat emperor (Lethrinus miniatus, RTE) and a wide range of other reef-associated fish species (OS) including other cods (mainly Serranidae), other emperors (Lethrinidae) and tropical snappers (mainly Lutjanidae), landed as dead fish or processed as fillets, and sold on the domestic market. The commercial fishery spans a broad latitudinal range along

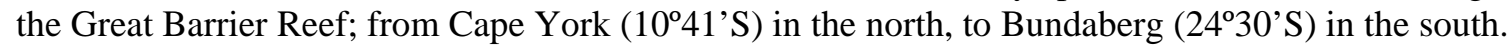

The commercial fishery consists of a wide diversity of operations, from single small vessels fishing short (24 to 48 hour) trips, to larger operations using a mother vessel and a varying number of tender boats, undertaking trips of up to 2.5 weeks duration. In addition, fishing businesses display varying strategies regarding their targeted fishing effort and catch composition. Some focus solely on CRFFF species, in particular the landing of live CT, while others target a broader range of species, outside of the CRFFF, using hook and line as well as other fishing apparatus (e.g. nets, pots, trawl).

The commercial fishery is managed primarily via a range of input and output controls detailed in the 2003 Coral Reef Fin-Fish Management plan [13]. These controls include: 
1. technical regulations regarding maximum vessel length (20 meters), number of lines per fisher and number of hooks on lines (no more than 3 fishing lines per fisher at a time, and no more than six hooks or lures attached to the lines) and minimum and maximum sizes of fish;

2. limited entry since 1984, through the issue of commercial fishing licences, which authorise the use of a primary boat (and identified tenders), to fish within the fisheries endorsed by fishery symbols on the licence. There are currently 369 licences authorised to operate in the CRFFF, of which approximately two thirds were recorded to be active in recent years [14]. Symbol endorsements on the licences determine the regions in which a licence holder is entitled to fish, as well as the species which can be caught (the symbol "RQ" allowing catch of CRFFF species), the fishing techniques, and the maximum number of tenders which can be used in the fishing operation;

3. commercial Total Allowable Catch (TAC) Limits. TAC limits were established in 2004 based on historical catch records. The available TACs are: CT 1214 Tons, RTE $~ 615$ Tons, and OS 902 Tons;

4. allocation of the commercial TAC via individual transferable quota units (ITQs). The TACs were allocated as line units to individual licence holders in 2004 on the basis of 1 unit $=1 \mathrm{~kg}$ (whole weight) of allowable landings of a particular species group. These entitlements are valid only if its owner also holds an RQ symbol that is in force for that particular year. A number of rules also apply to landings including designated landing points and prior notice of landing. Additional regulations also apply to the filleting of fish prior to landing;

5. tradability of both input and output entitlements. Licences can be permanently sold or temporarily leased; fishery symbols can be transferred between licences; and individual line units can also be sold or leased between RQ symbols; and

6. seasonal spawning closures (currently two 5 day closures in October and November).

In addition, the fleet predominantly operates in the area covered by Great Barrier Reef Marine Park (GBRMP) Zoning Plan 2003. Approximately 33\% of the Great Barrier Reef Marine Park comprises notake marine reserves and the fishery is required to operate outside of these reserve areas.

In 2010-11, total landings by the fishery amounted to approximately 1600 tons and estimated total gross returns of approximately $\$ 44$ million $^{1}$. This was composed of 763 tons of live CT (49\% of total RQ landings) and 115 tons of dead CT, live CT generating the greatest share (81\%) of total gross returns from the fishery (\$36 million, see Figure 1) due to the much higher first sale price of this product category ( $\$ 47 / \mathrm{kg}$ on average). With lower average sale prices (around $\$ 10 / \mathrm{kg}$ for RTE and $\$ 7 / \mathrm{kg}$ for OS), landings of these species which represented approximately $43 \%$ of total landings led to an estimated gross return of approximately $\$ 5.6$ million, or less than $13 \%$ of the total returns from the fishery (Figure 1).

\section{Figure 1 - about here}

The fishery has undergone significant changes since the introduction of the Fishery's (Coral Reef Fin Fish) Management Plan 2003 and its associated management, and the Great Barrier Reef Marine Park Zoning Plan 2003 (Zoning Plan). 135 tonnes of CT, 73 tonnes of RTE and 103 tonnes of OS quota and 45 associated RQ symbols were bought out in a structural adjustment package associated with the introduction of the Zoning Plan. After these changes there was an initial increase in catch rates and landings of CT up to a peak in 2008-2009 where the entire TAC for these species was nearly landed. This was followed by a drop in catch rates, that operators in the fishery largely attributed to the ecological

\footnotetext{
${ }^{1}$ Based on estimated annual average prices of the different product forms landed by the fishery.
} 
impacts of Cyclones Hamish (March 2009) and Yasi (February 2011), which led to a significant drop in fishing effort and catches in recent years (Figure 2).

\section{Figure 2 - about here}

This recent trend in the fishery has been reflected in the value of CRFFF access rights, in particular for quota units. Figure 3 reports the advertised nominal prices for CT quota sales and leases as observed in a specialized commercial fishing magazine (Queensland Fisherman) between January 2006 and December 2007, after the TACs were introduced (i.e. in the booming period of the CT fishery), and in the same magazine and quota broker web sites for months August 2011 to February 2012 and October 2012 to February $2013^{2}$. While the lowest prices observed in the booming period were reportedly around $\$ 45 / \mathrm{unit}$ to $\$ 50 /$ unit for sales and $\$ 3$ to $\$ 4$ for leases, sale prices as low as $\$ 11 /$ unit and lease prices as low as $\$ 1$ were recorded in $2012^{3}$, with a large variability in advertised prices.

\section{Figure 3 - about here}

\section{Approach}

The focus for the survey was the financial year 2010-11. The research team followed an approach which has been successfully applied in a variety of contexts, including French [15, 16] and English [17] commercial fisheries. This involved producing an updated description of the industry and developing a business profile taking into account the size and nature of fishing operations. The business profile was then used as a basis for a stratified random sampling of fishing operations, taking into account the coastal regions from which vessels operate ${ }^{4}$. Vessel owners and/or owner operators of the sampled vessels were interviewed face-to-face, using a structured questionnaire. The questionnaire was initially developed using the authors' background knowledge with respect to the collection of economic data in a range of Australian, as well as European fisheries (Table 1). It contained three main components on (i) vessel activity in the year under consideration; (ii) costs and earnings associated with the operation of the fishing vessel; and (iii) a broader set of questions regarding the history of the respondent's involvement in the CRFFF, as well as current perceived key drivers of profitability and possible responses to changes in catch rates in the areas usually fished. The survey approach was finalized in close collaboration with active participants in the CRFFF, license and quota holders, Fisheries Queensland and the Great Barrier Reef Marine Park Authority ${ }^{5}$.

Table 1 - about here

\footnotetext{
${ }^{2}$ Quota sale and lease prices are not recorded by the management system.

${ }^{3}$ In July 2012, sale prices as low as \$11/CT unit were reported by an industry member in an ABC program. In February 2013 an advert was seen offering to pay $\$ 9 / \mathrm{kg}$ for the purchase of CT quota.

${ }^{4}$ In addition, the fleet profile will be used as a basis to allocate surveys of voluntary participants who contacted the survey team, to the strata in the sample.

${ }^{5}$ The survey was administered between November 2011 and June 2012. The data collected was anonymized and entered into a database via a dedicated data entry tool. At the time of writing of this paper, analysis of the data collected is still underway.
} 


\subsection{Definition of a Coral Reef Fin Fish Fishery Business profile}

The target population for the survey was defined as the owners or owner-operators of vessels that were actively involved in the CRFFF in 2010-11. In collaboration with Fisheries Queensland, an initial list of vessels identified by their boat marks was created, based on the vessels that held an RQ symbol on their fishing license in 2010-11. This list contained 369 individual boat marks, for which individual vessel technical characteristics, total fishing effort and its distribution across RQ and non-RQ fishing, annual landings information from logbooks and total unloads of RQ species from the quota monitoring system were recorded. Approximately a third (115) of the boat marks selected through this initial process were inactive in the reference year (2010-11), so were excluded from the population frame. Another 41 vessels had no unloads of RQ species recorded for the reference year (i.e. had not fished in the CRFFF in 201011 ), so were also excluded. This led to a remaining list of 213 vessels for which all technical, effort and landings information was available, and which had landed some RQ species in the reference year.

Identification of groups of fishing businesses with similar technical vessel characteristics and activity profiles was based on a cluster analysis. This used information available to describe vessel characteristics (length, breadth, draft, engine power, number of tenders), as well as characteristics of the businesses' fishing activity including landings by fishing method, proportion of CT landed live, and effort in days fished which was categorized into total effort, effort devoted to fishing in the CRFFF, and effort devoted to fishing in other fisheries. Symbol endorsements held, which determine the ability for fishing businesses to access and utilize different fisheries / areas), were included as descriptive variables of the fishing business groups identified in the cluster analysis.

\section{Figure 4 - about here}

The hclust hierarchical cluster analysis function in $\mathrm{R}$ was used to identify fishing business groups displaying similar characteristics. hclust relies on the specification of a dissimilarity function between observations (Euclidean distance was chosen for the purpose of this analysis), and uses these distances to iteratively aggregate individuals into a hierarchical set of clusters [18]. Visual evaluation of the dendogram presenting the hierarchy of clusters was used to identify an appropriate number of business groups within the fishery. Given that the objective of the analysis was to establish fishing business groups with homogeneous characteristics, and the need to further allocate these into main regions of the Queensland coast that would be surveyed ${ }^{6}$ (Figure 4), a smaller number of clusters was favored.

\section{Results}

\subsection{Activity profiles}

Analyses led to the identification of three distinct groups of fishing businesses (Table 2) which comprised differing vessel specifications and levels and types of fishing activity (Figure 5). The groups were used as a basis to define a stratified random sample of fishing business operators to interview, taking into account the regional distribution of these three groups.

\footnotetext{
${ }^{6}$ The definition of these regions was based on previous studies of the CRFFF, including the Effects of Line Fishing project, expert knowledge of the key stakeholders consulted while developing the approach, and existing information on the spatial distribution of landings by the fleet along the coast.
} 
Table 2 - about here

Overall, the fishing business profile led to the clear differentiation of (i) a large group of Generalist Line Fishers, operating smaller vessels, many of whom were only very partially active in 2010-11, relatively focused on line fishing but only partially focused on CRFFF catch; (ii) a group of Dedicated live CT fishers, operating larger vessels and focused on live CT catch, and contributing to three quarters of the total harvest from the CRFFF, and (iii) a group Diversified fishers operating medium-sized vessels that operate across a range of fisheries including the CRFFF, which provides a small share of their total harvest, and whose RQ harvest only represents a small proportion of the total RQ harvest.

The first group (Generalist Line Fishers) comprised the largest number of fishing businesses (133). These generally utilized smaller average size vessels, and had lower average levels of fishing activity in 2010-11 (Figure 5). They mainly landed line-caught species, both from the CRFFF and from other fisheries, although some net-caught fish was also landed. The greatest share of CT landing by this group was composed of dead fish. Altogether, while representing a large number of fishing businesses, this group only contributed to $20 \%$ of the total unloads of RQ species.

The second group (Dedicated live CT fishers) comprised a relatively smaller number of fishing businesses (56), utilizing vessels of larger than average size and supporting a larger number of tenders. These fishing businesses had much higher levels of average annual fishing effort, were exclusively focused on line fishing and targeted mainly CT. They landed mostly live CT (90\% of all CT harvest) and altogether, this group accounted for 75\% of total landings of RQ species in 2010-11.

\section{Figure 5 - about here}

Caption to Figure 5: 1: Generalist Line Fishers; 2: Dedicated live CT fishers; 3: Diversified fishers. Top left panel: average annual landings per vessel (kg; colour legend indicated to the right of the graph); Top right panel: Total RQ landings by vessel group ( $\mathrm{kg}$ ) (red bars, left axis) and proportion of fish landed live (white floating bars, right axis); Bottom left: proportion of vessels holding endorsements for Trawl (5-9), Trawl (1,M), Spanish Mackerel (SM), Shark (S), Net (N) and Crab (C) fisheries (color code in legend below graph); Bottom right: average number of fishing days per vessel in 2010-11 (color code in legend below graph).

The third group (Diversified fishers) comprised a small (24) group of fishing businesses, utilizing medium-sized vessels, operating in a wide range of fisheries, of which the CRFFF only constituted a small component in terms of both fishing effort and landings. This group had levels of activity in 2010-11 that were comparable to those observed for the second group of businesses. These operators only harvested a small share of the total landings of RQ species, which constituted on average less than a quarter of their respective annual harvest, while crab and net landings represented the largest share. CT landings by these businesses were mainly dead fish ( $80 \%$ of all CT harvested was landed dead).

\subsection{Quota ownership}

Another important dimension in the characterization of the CRFFF relates to the structure of quota ownership in the fishery. The typology developed by Van Putten et al [19] for the Tasmanian rock lobster fishery was used to describe the status of businesses involved in the quota market for CRFFF species. This typology distinguishes between different positions agents may have on the quota market, depending on whether they are actively involved in fishing and/or in ITQ lease trading. The categories of the Tasmanian Rock Lobster quota market typology are "investors", who hold quota which they lease out; "independent fishers" who catch the quota they own and do not participate in the quota market; "income 
supplementers" who derive income from both fishing their quota and leasing some out; "lease dependent" operators who depend on leasing in quota for their catch; and "quota redistributors" who are involved in both leasing quota in and leasing quota out. This typology was applied to ownership and usage of CT quota units in the CRFFF in 2010-11, as live CT landings were the dominant contributor to the value of landings in the fishery.

Ownership of CT catch entitlements was distributed across all of these groups ${ }^{7}$, with investors holding the greatest share (42\%) of total available catch entitlements. Lease dependent fishers held only $11 \%$ of the available CT quota but harvested more than two thirds (69\%) of the total landed CT in 2010-11. Independent operators held $13 \%$ of total available CT quota and represented a similar proportion of total landings. The same proportion of CT quota was held by operators who derived income from both catching some of their CT quota, and leasing part of it out. A group of inactive quota owners, who neither leased nor fished the quota they owned in 2010-11, was also identified (see [20] for more details).

\section{Figure 6 - about here}

\section{Discussion: key drivers of micro-economic viability in the fishery}

While the analysis of survey results is still underway, this fishing business profile as well as qualitative information gained in developing it in collaboration with stakeholders, provides an understanding of the key drivers of profitability in the CRFFF, as well as business-level characteristics which may determine how these drivers affect individual enterprises. A synthetic view of the drivers of profitability in the CRFFF, based on a standard economic representation of the fishing business, is presented in Figure 7. Unit profit is determined by the difference between the value of a unit of output and the costs of producing this unit.

Output value is directly influenced by first sale prices, which are themselves influenced by a range of factors including the composition of landings, demand for the different categories of product landed, as well as exchange rates where the output is exported. In the case of CT, qualitative information gained in the process of administering the survey seems to indicate that sale prices remained relatively high in 2010-11, despite a high Australian dollar, probably due to the continued growth in demand for live fish in China and relatively low levels of CRFFF CT landings. On the other hand, prices for dead fish, particularly for other species than CT landed by the CRFFF, appear to remain relatively low, due to the competing supply of imported low-price fish products on the Australian domestic market.

Production costs result from the effort required to produce a unit of output and the unit costs of effort, each of which is also subject to a range of external influences. The effort required to land a unit of fish (i.e. catch rates) can be influenced by a combination of short-term and longer-term environmental and ecological factors. In the case of CT, as already stressed, a pair of severe cyclones is deemed to have negatively impacted both fishing opportunities and the catch rates of CT, leading to a drop in catches in the last three years [21]. Meanwhile, it would seem that unit costs of fishing have tended to increase, in particular as a result of increased fuel prices, and the difficulty of maintaining good crew in the presence of alternative opportunities related to the development of the Australian mining industry.

\footnotetext{
${ }^{7}$ In addition, a number of quota owners appeared to be inactive in 2010-11, in that they neither caught nor traded the quota they held on the quota market. This would seem to indicate the existence of transaction costs on this market which discourage trades from occurring, despite this leading to costs for quota owners who decide not to fish their quota themselves, in terms of both cash costs (annual administration fees payed on units owned) and opportunity costs of not leasing their quota out. See [20] for a more detailed analysis of the CT quota market characteristics.
} 


\section{Figure 7 - about here}

Overall, the recent drop in activity and catch in the CRFFF has largely resulted from a drop in CT fishing, which resulted from the combination of environmental and economic drivers affecting CT catch rates and unit costs of harvesting. This, in turn, has driven the sale and lease prices of CT quota units down, as was illustrated in Figure 3. Additional weaknesses of the ITQ management system identified, including practical difficulties in linking landed weights of fish to quota units, inspection rates of quota landings and resources for auditing quota and sales could also have affected quota unit prices. While this qualitative evaluation may apply at the industry level, the actual consequences of this at the individual business-level may be quite variable depending on the structure of businesses involved in the fishery. On the basis of the fishing business profile described in the previous section, the following main distinctions can be identified:

Firstly, the profitability and behavior of businesses centrally engaged in fishing for live CT (i.e. those belonging to the second fishing business group in our profile) will be more directly affected by the circumstances mentioned above, than for operators who engage in a broader range of fisheries. This is illustrated by the "level of dependence" box on the right-hand side of Figure 8. In particular, operators belonging to the group of Diversified fishers in our fishing business profile, have more alternative fishery options than the second group, and could be expected to redirect their effort towards more profitable fisheries (if any) when returns on CT fishing decrease. On the other hand, effort in the CRFFF by Diversified fishers could increase, not because of improved circumstances in this fishery, but because of degraded conditions in the alternative sectors in which they are entitled to operate, hence leading to a weaker correlation between economic circumstances in the CRFFF, business profitability and fishing activities for this group. There is an option for CRFFF operators to shift between the landing of live CT and the landing of dead fish of a broader set of species (e.g. OS species). Indeed this option was exercised in the early years of the live CT fishery of the CRFFF and was analyzed by [22]. However, given the low sale prices for dead fish and the time and costs associated with converting storage space on board from the handling of live to the handling of chilled / frozen fish, this currently does not seem to constitute a viable option for vessels dedicated to the catch of live CT.

Secondly, the structure of quota ownership by individual businesses involved in the fishery may also be crucial in determining the actual micro-economic impacts of the circumstances recently observed in the CT component of the fishery. As illustrated in Figure 8, profitability of all operators actively involved in fishing will be negatively affected (orange arrows) by unfavorable catch rates and harvesting costs. However, not all will be affected to the same degree; income supplementers will be subjected to both reduced profitability of their harvests and loss of income from reduced lease prices. On the other hand, lease dependent fishers, while affected by the decreased profitability of fishing operations, will benefit from reduced lease prices, which reduce their operating costs. Investors, since they only derive income from leasing out quota, will directly suffer from the reduced lease prices. Larger investors that invested quite heavily in the fishery are also likely to be servicing loans against the quota they hold, making a reduction in lease prices or inability to lease quota out even more problematic.

Finally, the short-term financial viability of fishing operations also seems to be impacted by the actual set-up of the fishing business in terms of its catching operations. Qualitative information gained in the course of carrying out this research showed that owner-operators do not always pay themselves a salary for the time devoted to operating the vessel, particularly when the economic conditions of operation are difficult. While this may not be a sustainable solution in the long-term, it provides these operators with a buffer in periods of low profitability which businesses who hire skippers to operate their vessels do not have, as they will need to pay the skipper a salary for him to stay involved with the business. This 
characteristic of owner-operated fishing businesses, illustrated by the blue box to the right of Figure 8, is often encountered in small scale commercial fisheries [23].

\section{Figure 8 - about here}

\section{Conclusion}

The background analysis of business structures encountered in the commercial component of the CRFFF confirms that using the term "Fishers" to describe them all would be misleading, as it would not adequately reflect the diversity in business structures used to engage in the fishery. Depending on their structure, different fishing businesses will be impacted differently by externally driven changes in the factors that affect the profitability of fishing in the CRFFF, and subsequently their short-term and longterm economic viability. In turn, this can be expected to affect incentives for investment to flow towards particular business structures in the fishery, and for individual businesses to support alternative approaches aimed at restoring the overall economic health of the fishery.

Important dimensions defining business structures include their scale, and the extent to which businesses are specialized or maintain access to range of fishing activities or other business activities which they can shift their fishing effort to. Another important dimension relates to the structure of asset ownership of businesses, particularly with regards to access entitlements, including both licences ${ }^{8}$ and quota. With the development of access regulations including licenses and quota, access rights have become a key component of the capital assets required for a commercial operator to be involved in the fishery. Depending on their asset ownership structure (i.e. whether they own or lease the licences and quota they require to operate, and whether they derive income from these other than through directly fishing), businesses will not be facing the same risks and will not be impacted in the same ways by externally driven changes in their environment. Hence, the same overall changes affecting the fishery may generate different responses from different businesses, which may explain the differences in views expressed on future management of the fishery, particularly as regards the adequate level of TAC for CT. As stressed by [24], this is still a poorly understood dimension of investment in fisheries, when it is becoming a dominant feature in the quota managed fisheries like the CRFFF, where a combination of access entitlements is required to commercially harvest fish.

Finally, it also became apparent in the course of carrying out this analysis that a key dimension of fishing businesses is whether the vessels are operated by their owner, or whether they are operated by a hired skipper. In the latter case, it has been shown elsewhere that the relevant measure of profitability should be based on the owner-operator's income, after adequate returns on investment have been paid [23]. From the qualitative information available, it appears that owner-operators faced with difficult conditions such as those recently experienced in the CRFFF can adjust these returns downwards, at least temporarily, in order to remain viable. In contrast, businesses that have chosen to operate with hired skippers are more limited in the adjustments they can make to skipper remuneration and levels of returns on investment (i.e. reducing skipper wages will entail a risk of losing competent skipper and dependent crew).

\section{$7 \quad$ References cited}

1. van Putten, I.E., et al., Theories and behavioural drivers underlying fleet dynamics models. Fish and Fisheries, 2012. 13(2): p. 216-235.

\footnotetext{
${ }^{8}$ Some operators derive income from leasing out a licence. While this may constitute another important dimension of business structures in the CRFFF, the data regarding this aspect of the fishery has not been considered in our analysis to date.
} 
2. Fulton, E.A., et al., Human behaviour: the key source of uncertainty in fisheries management. Fish and Fisheries, 2011. 12(1): p. 2-17.

3. Soulie, J.-C. and O. Thebaud, Modeling fleet response in regulated fisheries: An agentbased approach. Mathematical and Computer Modelling, 2006. 44(5-6): p. 553-564.

4. Wilen, J.E., et al., Avoiding surprises: Incorporating fisherman behavior into management models. Bulletin of Marine Science, 2002. 70(2): p. 553-575.

5. Wilen, J.E., Fishermen behavior and the design of efficient fisheries regulation programs. Journal of Fisheries Research Board of Canada, 1979. 30.

6. Mapstone, B.D., et al., Management strategy evaluation for line fishing in the Great Barrier Reef: Balancing conservation and multi-sector fishery objectives. Fisheries Research, 2008. 94(3): p. 315-329.

7. Hamon, K., et al., Adaptive behaviour of fishers to external perturbations: simulation of the Tasmanian rock lobster fishery. Reviews in fish biology and fisheries, 2013: p. 1-16.

8. Gordon, H.S., The Economic Theory of a Common-Property Resource: The Fishery. Journal of Political Economy, 1954. 62(2): p. 124.

9. Little, L.R., et al., An agent-based model for simulating trading of multi-species fisheries quota. Ecological Modelling, 2009. 220(23): p. 3404-3412.

10. Little, L.R., et al., ELFSim--A model for evaluating management options for spatially structured reef fish populations: An illustration of the "larval subsidy" effect. Ecological Modelling, 2007. 205(3-4): p. 381-396.

11. Fernandes, L., et al., Establishing Representative No-Take Areas in the Great Barrier Reef: Large-Scale Implementation of Theory on Marine Protected Areas. Conservation Biology, 2005. 19(6): p. 1733-1744.

12. Henry, G. and J.M. Lyle, The national and recreational and Indigenous fishing survey, 2003, Australian Governement Department of Agriculture, Fisheries and Forestry: Canberra. p. 190.

13. Queensland Government, Fisheries (Coral Reef Fin Fish) Management Plan 2003 Reprinted as in force on 1 July 2010, S.o. Queensland, Editor 2010: Brisbane. p. 85.

14. Fisheries Queensland, Annual status report 2010 - Coral Reef Fin Fish Fishery, 2011, The State of Queensland, Department of Employment, Economic Development and Innovation.: Brisbane. p. 23.

15. Van Iseghem, S., et al., Ensuring representative economic data: survey data-collection methods in France for implementing the Common Fisheries Policy. ICES Journal of Marine Science: Journal du Conseil, 2011. 68(8): p. 1792-1799.

16. Daurès, F., et al., Fishing fleet typology, economic dependence, and species landing profiles of the French fleets in the Bay of Biscay, 2000-2006. Aquatic Living Resources, 2009. 22(04): p. 535-547.

17. Pascoe, S., C. Robinson, and L. Coglan, Economic and financial performance of the UK English Channel fleet., in CEMARE Report1996, University of Portsmouth: Portsmouth, UK. p. 55.

18. Teetor, P., R Cookbook2011: O'Reilly Media, Inc.

19. van Putten, I. and C. Gardner, Lease quota fishing in a changing rock lobster industry. Marine Policy, 2010. 34(5): p. 859-867.

20. Innes, J., et al., The Australian Coral Reef Fin-Fish Fishery ITQ Market, in Visible Possibilities: The Economics of Sustainable Fisheries, Aquaculture and Seafood Trade. Sixteenth Biennial Conference of the International Institute of Fisheries Economics and 
Trade, A.L. Shriver, Editor 2012, International Institute of Fisheries Economics and Trade: Dar es Salaam, Tanzania.

21. Tobin, A., et al., Adapting to change: minimising uncertainty about the effects of rapidlychanging environmental conditions on the Queensland Coral Reef Fin Fish Fishery. Final Report to the Fisheries Research \& Development Corporation., in Fishing \& Fisheries Research Centre Technical Report2010, Fishing \& Fisheries Research Centre, James Cook University: Townsville, Australia. p. 172.

22. Muldoon, G.J., Innovation and capacity in fisheries: value-adding and the emergence of the live reef fish trade as part of the Great Barrier Reef reef-line fishery., in School of environmental and earth sciences2009, James Cook University: Townsville.

23. Boncoeur, J., et al., On the (ir)relevance of rates of return measures of economic performance to small boats. Fisheries Research, 2000. 49(2): p. 105-115.

24. Nøstbakken, L., O. Thébaud, and L.-C. Sorensen, Investment behaviour and capacity adjustment in fisheries: a survey of the literature. Marine Resource Economics, 2011. 26: p. 95-117. 
Figure 1 - Estimated 2010-11 gross turnover (AU\$ Million) of the CRFFF (Left) and total landings (Tons) in 201-11 (right). Source: own calculations based on Fisheries Queensland landings data and estimated average prices per species group
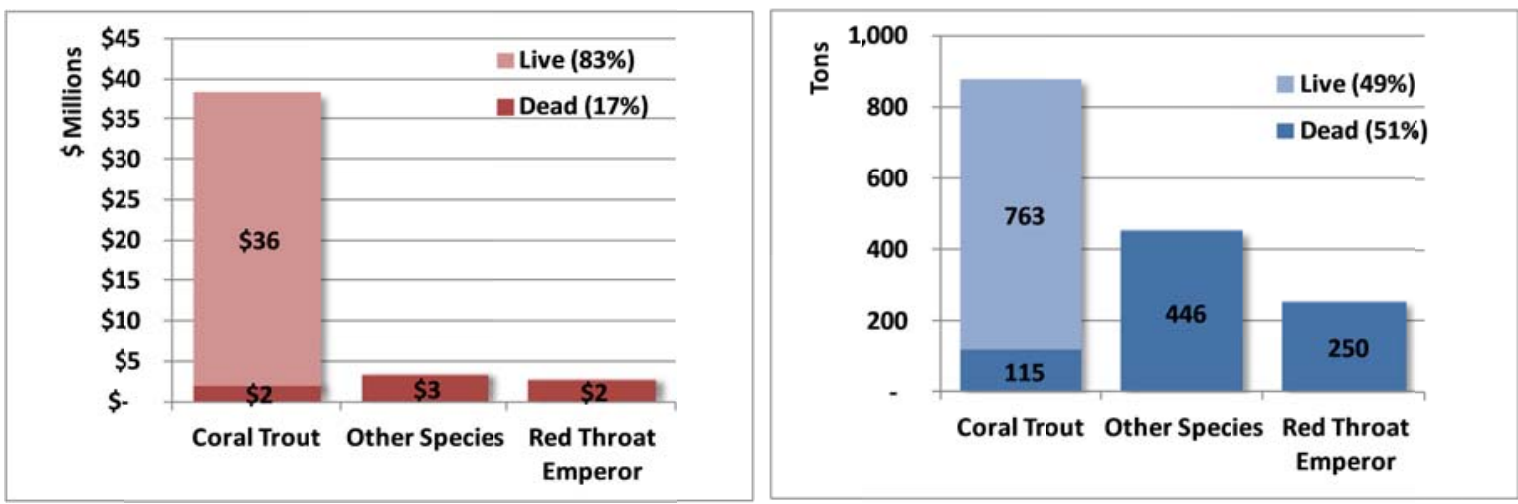

Figure 2 - Landings in 2008-09 and 2010-11, and Total Allowable Landing limits. Source: Fisheries Queensland

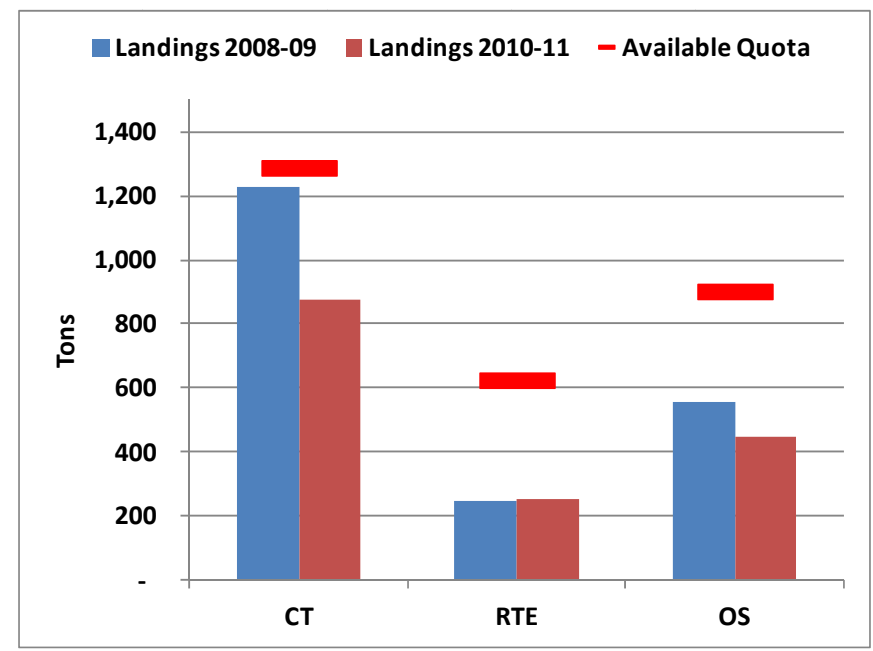


Figure 3 - Changes in monthly advertised CT nominal quota lease and sale prices (\$/unit), September 2004 to December 2007, August 2011 to February 2012 and October 2012 to February 2013

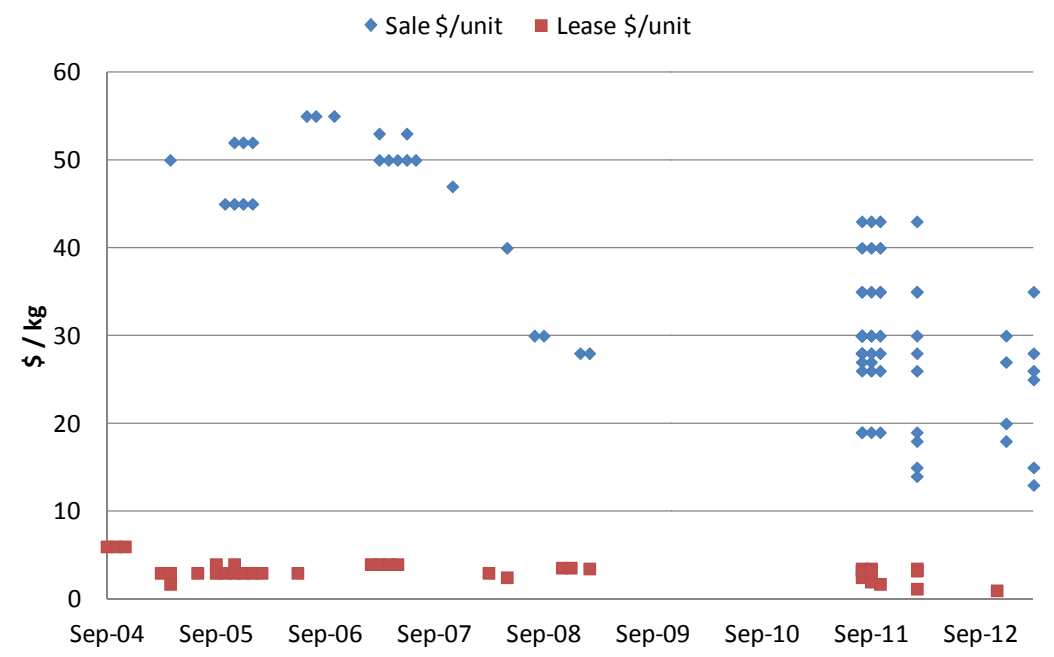

Figure 4 - Seven regions used to structure the CRFFF economic survey (Large font: Region, Small font: main landing sites per region, Colors represent link between landing sites and regions)

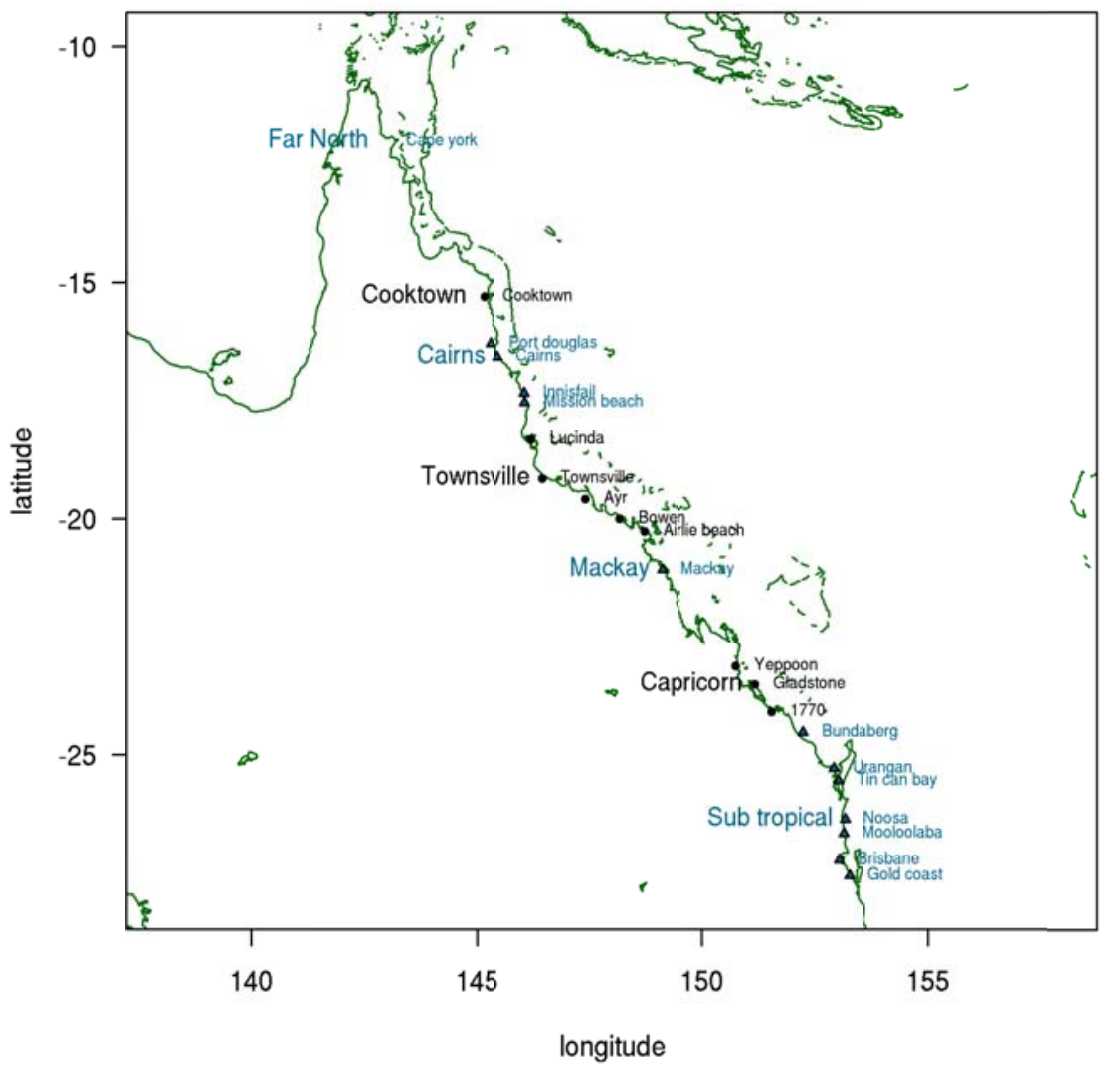


Figure 5 - Main characteristics of the fishing businesses in each group. Source: own results based on Fisheries Queensland data

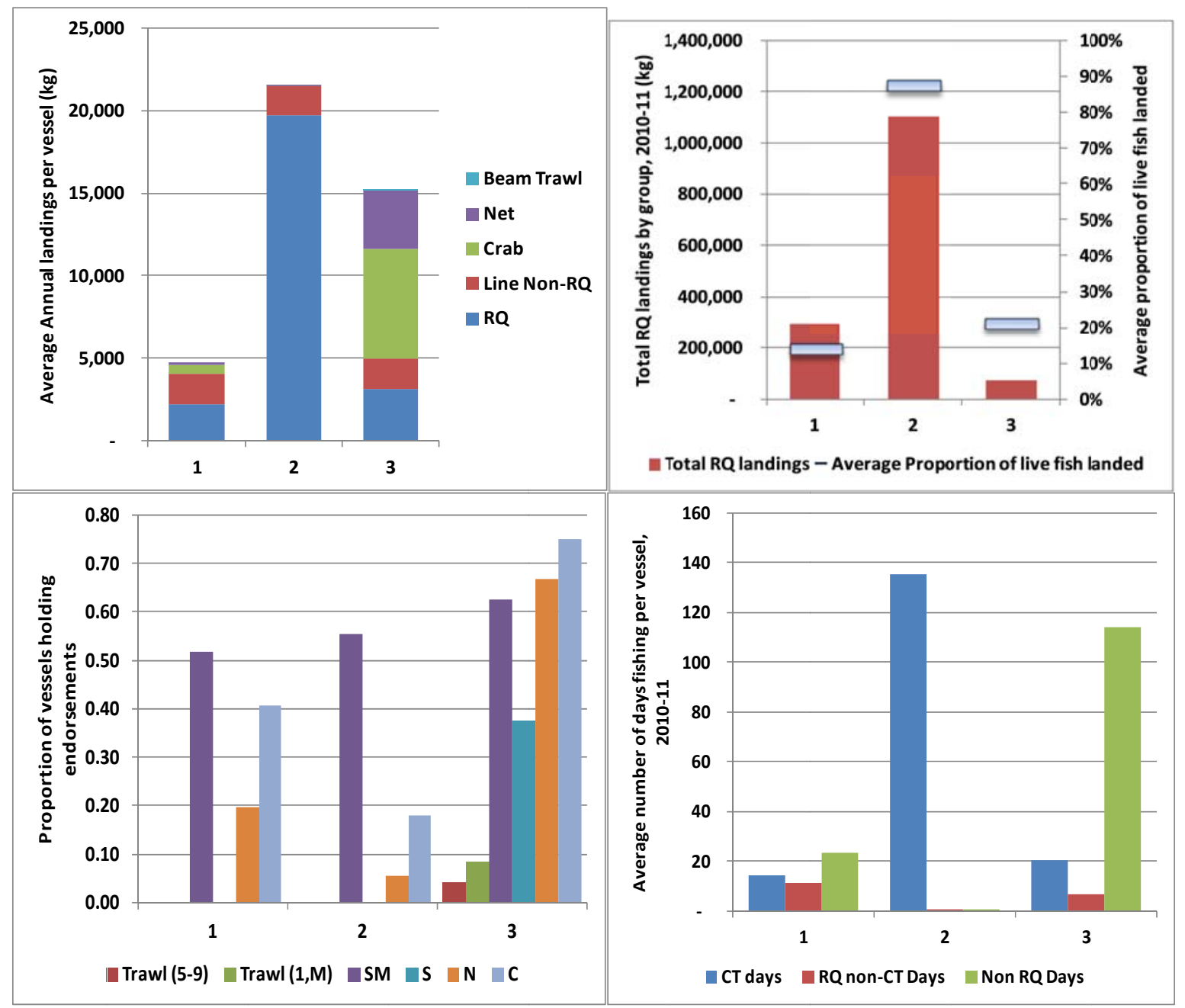


Figure 6 - CT quota ownership \& usage by type of operator, 2010-11 (Source: Fisheries Queensland)

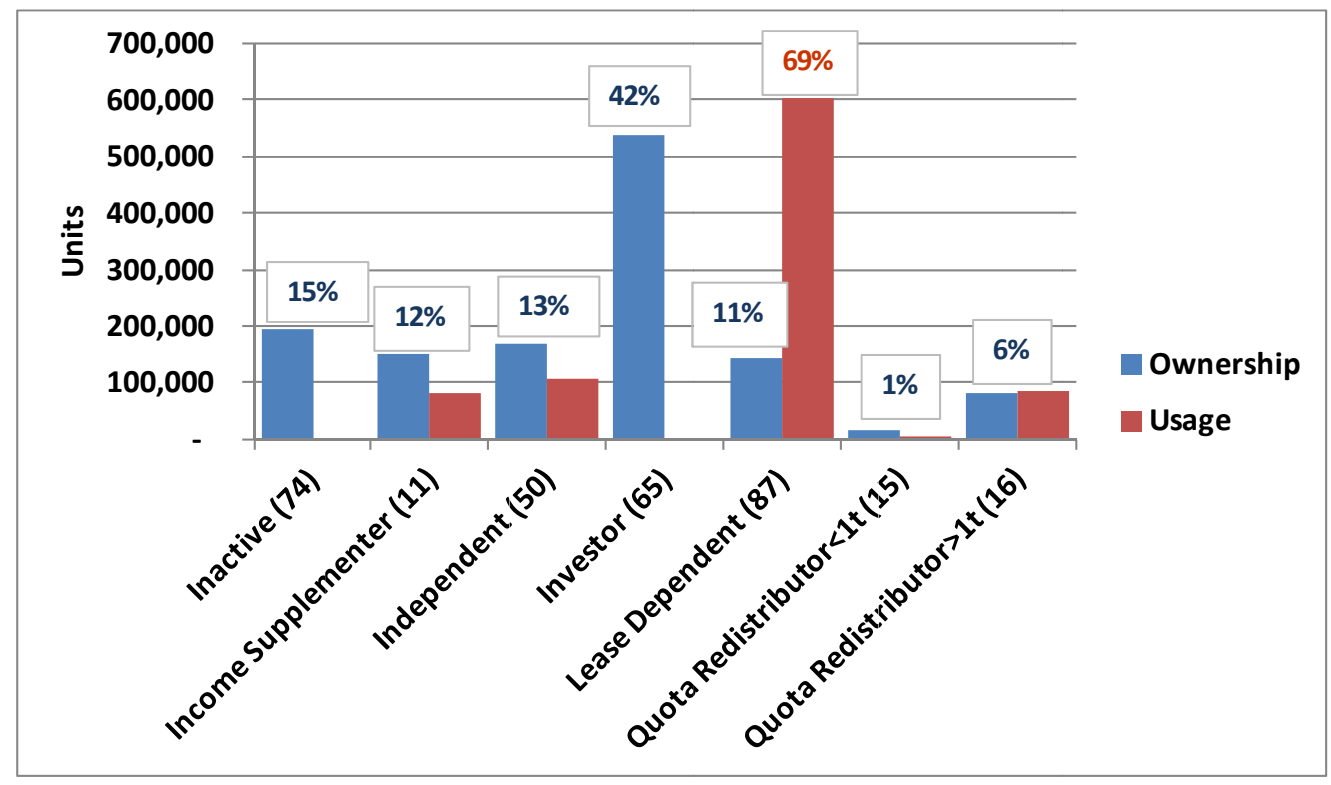

Figure 7 - Key drivers of micro-economic profitability in the fishery (green boxes: direct determinants of profitability; blue boxes: external drivers)

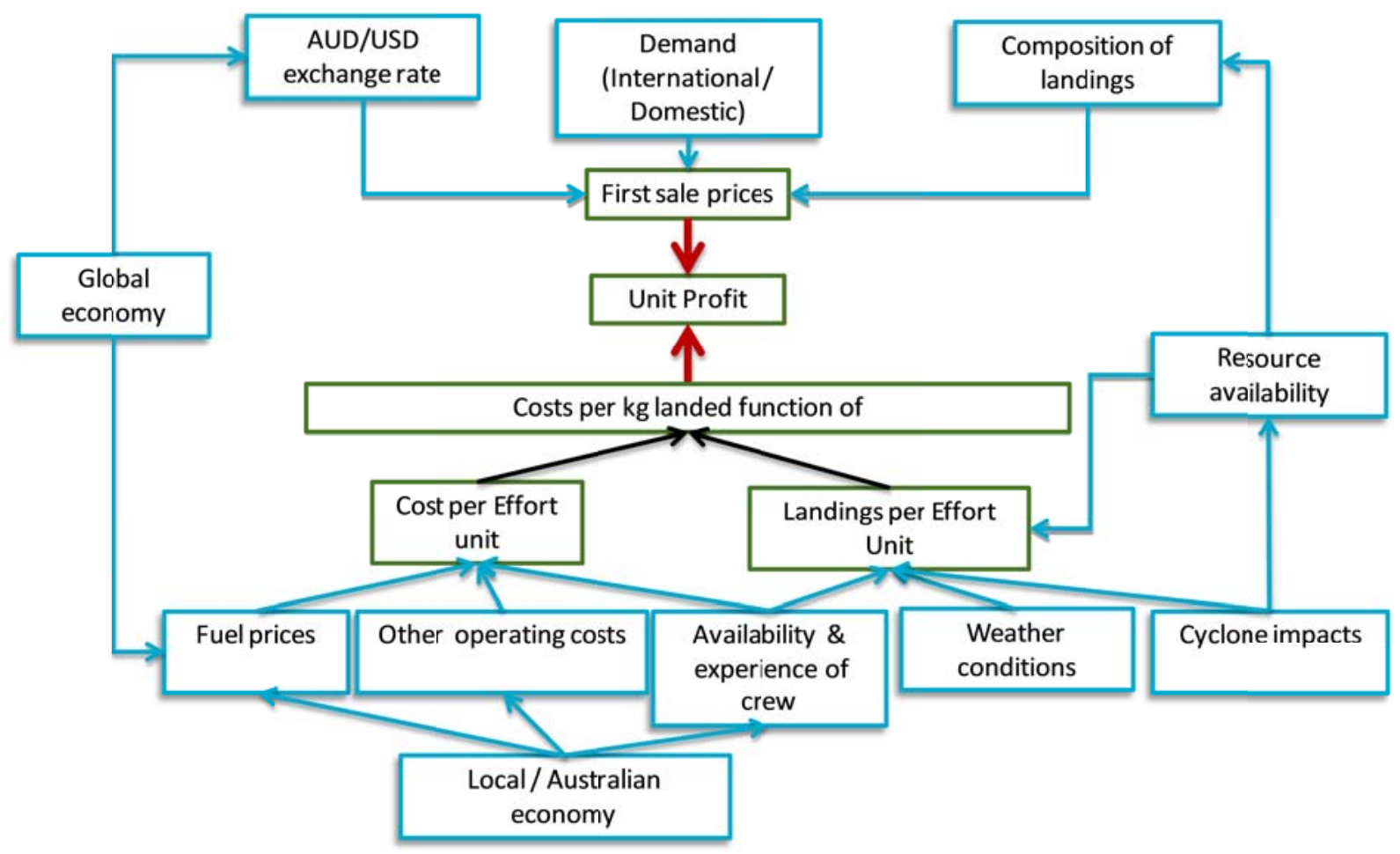


Figure 8 - Drivers of micro-economic profitability depending on business structure (orange arrows reflect negative impacts, green arrows reflect positive impacts)

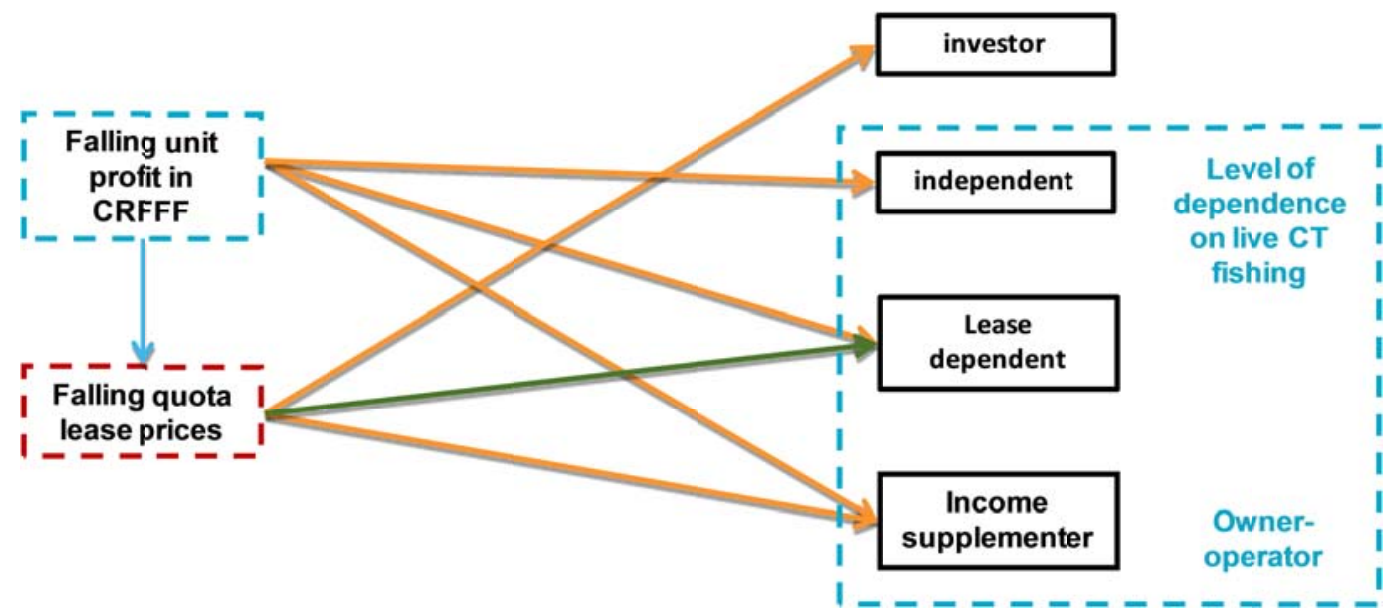


Table 1 - Previous economic surveys of commercial fisheries which were used to define the structure of the questionnaire applied to the CRFFF

\begin{tabular}{|c|c|c|c|}
\hline Fishery surveyed & Country/Region & Organization & $\begin{array}{l}\text { Years for which } \\
\text { data was collected }\end{array}$ \\
\hline Moreton Bay Otter Trawl & $\begin{array}{l}\text { Moreton Bay, } \\
\text { QLD, Australia }\end{array}$ & $\begin{array}{l}\text { Queensland Department } \\
\text { of } \quad \text { Employment, } \\
\text { Economic Development } \\
\text { and Innovation }\end{array}$ & 2010 \\
\hline Marine Scalefish Fishery & South Australia & EconSearch Pty Ltd & 2009-10 \\
\hline $\begin{array}{l}\text { Eastern Tuna and Billfish } \\
\text { Fishery \& Southern and } \\
\text { Eastern ScaleFish and Shark } \\
\text { Fishery }\end{array}$ & $\begin{array}{l}\text { Commonwealth, } \\
\text { Australia }\end{array}$ & $\begin{array}{l}\text { Australian Bureau of } \\
\text { Agricultural and } \\
\text { Resource Economics }\end{array}$ & 2007-08 and 2008-09 \\
\hline $\begin{array}{l}\text { Queensland commercial } \\
\text { fisheries }\end{array}$ & $\begin{array}{l}\text { Queensland, } \\
\text { Australia }\end{array}$ & $\begin{array}{l}\text { Department of Primary } \\
\text { Industries and Fisheries }\end{array}$ & 2007/08 \\
\hline $\begin{array}{l}\text { Reef line fishery (Coral Reef } \\
\text { Fin Fish Fishery) }\end{array}$ & $\begin{array}{l}\text { Queensland, } \\
\text { Australia }\end{array}$ & James Cook University & 1994-1999 \\
\hline French fishing fleet & France & $\begin{array}{l}\text { Institut Francais de } \\
\text { Recherche pour } \\
\text { l'Exploitation de la Mer }\end{array}$ & $2000-2010$ \\
\hline UK Fishing fleet & UK & Seafish & 2001 \\
\hline English Channel fishing fleet & UK & $\begin{array}{l}\text { University } \\
\text { Portsmouth }\end{array}$ & 1995-95, 1997 \\
\hline North Sea beam trawlers & North Sea & $\begin{array}{l}\text { University } \\
\text { Portsmouth }\end{array}$ & 1990-2004 \\
\hline
\end{tabular}

Table 2 - Technical characteristics of vessels comprising each Fishing Business Group

\begin{tabular}{|c|c|c|c|c|}
\hline Fishing Business Group & $\begin{array}{l}\text { Number } \\
\text { of vessels }\end{array}$ & $\begin{array}{l}\text { Average } \\
(\mathrm{m}) *\end{array}$ & $\begin{array}{r}\text { Length Average } \quad \mathbf{E} \\
\text { Power (kw)* }\end{array}$ & $\begin{array}{lr}\text { Engine Average } & \text { Number } \\
* & \text { Tenders per Vessel* }\end{array}$ \\
\hline \multicolumn{2}{|c|}{1 - Generalist Line Fishers 133} & $8.6(2.4)$ & 143.5 (83.9) & $1.3(1.1)$ \\
\hline \multicolumn{5}{|c|}{2 - Dedicated live CT } \\
\hline fishers & 56 & $14.5(2.7)$ & $175.5(88.3)$ & $4.5(1.3)$ \\
\hline$\underline{3}$ - Diversified fishers & 24 & $9.9(2.7)$ & $164.9(93.2)$ & $1.3(1.4)$ \\
\hline Grand Total & 213 & $10.3(3.6)$ & $154.1(87.3)$ & $2.1(1.9)$ \\
\hline
\end{tabular}

